\title{
Children's respiratory infections in Tianjin, China: associations with home environments and life styles
}

Da chao Lv

Tianjin University

Yuexia Sun ( $\nabla$ yuexiasun@tju.edu.cn )

https://orcid.org/0000-0001-6303-5436

Jing Hou

Tianjin University

\section{Pan Wang}

Tianjin University

Qingnan Zhang

Tianjin University

Jan Sundell

Tianjin University

\section{Research}

Keywords: Respiratory infections, Dry air perception, Condensation, Sun-cure bedding, Cesarean

Posted Date: December 31st, 2019

DOI: https://doi.org/10.21203/rs.2.19822/v1

License: (1) This work is licensed under a Creative Commons Attribution 4.0 International License. Read Full License 


\section{Abstract}

Background: Children spend most of their indoors time at home. This study is to identify the incidences of respiratory infections among children and their associations with home environments and life styles.

Methods: We conducted a cross-sectional study to identify the associations of home environments and lifestyles with respiratory infections among children aged 0-8 in the Tianjin area, China.

Results: The lifetime-ever incidences of croup, tuberculosis (TB), pneumonia and ear infection among children aged 0-8 in Tianjin area was $9.2 \%, 0.7 \%, 28.7 \%$ and $11.6 \%$. The incidence of common cold infections more than twice per year was $31.3 \%$. Home environment and life styles were strong risk factors for childhood respiratory infections. Dry air perception had the greatest associations with childhood pneumonia ( $\mathrm{PAF}=14.6 \%$ ) and common cold $(16.8 \%)$, while Cesarean delivery had the greatest association with croup (18.7\%) and ear infection (18.5\%). Daycare attendance accounted for $14.4 \%$ of the incidence of frequent common colds. Infrequent sun-curing bedding is a risk factor associated with pneumonia (11.2\%), ear infection (17.1\%) and frequent common colds (8.6\%).

Conclusions: Factors related to "modern" home environments and life styles are risks for childhood respiratory infections. Modifying such factors might reduce the respiratory infections among children.

\section{Introduction}

Infants and young children are more vulnerable to environmental exposure because their immune systems are not developed fully [1]. In 2017 alone, an estimated 5.4 million children under age 5 died world-wide, most from preventable causes [2]. The leading cause of under five mortality condition was respiratory infections, which accounted for $15 \%-16 \%$ and was second to prematurity [3]. However, there is no evidence for a robust relationship between the respiratory infections and genetic or racial factors $[4,5]$. People spend most of their time indoors, especially children [6, 7]. Household activities and environmental exposure at home are suspected to be risk factors for respiratory infections, especially in low income countries [8].

Home environmental exposures include chemical exposure from building materials and decoration, dampness and mould and environmental tobacco smoke (ETS) pre- and post-natally. Many studies $[9-11,12,13]$ have shown that dampness and mold in buildings are significantly associated with an increase of respiratory infections. People living in damp houses have been shown to be more likely to suffer from respiratory infections due to exposure to higher concentration of fungi and dust mites in damp environments [14] [15]. Exposure to home indoor air pollutants such as ETS [16] and chemical sources [17] have been also reported to be associated with respiratory infections among children.

Besides home environmental exposure, previous research has also shown that life style factors and biological factors are important determinants of children's health [18]. Sun-curing bedding and daily cleaning room are protective against respiratory infections [19]. Holberg et al [20] and Ball et al [21] have demonstrated that daycare attendance was the most common trigger of acquiring infections in the first 2 years of life. Occupancy level and type of daycare facility have been identified as important determinants of infection risk [22] [23]. The mode of delivery was found to affect early respiratory microbiota development, and this may play an important role in respiratory health later in life [24]. In addition, many studies in different countries had suggested that the exclusive and prolonged breastfeeding was protective for respiratory infections [25-27].

With China's increasing wealth and urbanization in the past 40 years, Chinese homes and life styles have changed dramatically. In urban areas, traditional Chinese residential buildings, Pingfang, have been replaced by high-rise apartments [28]. New furnishing materials have come into use [29]. Homes have been tightened in order to save energy, resulting in poor ventilation [30]. Along with this urbanization, a "modern" life style has been adopted. It is less convenient for residents in urban areas to sun-cure bedding. Fast food has become popular. Childbirth tends to be born by $\mathrm{C}$-section. Breastfeeding time has been reduced, and daycare is being started earlier.

In view of these changes in home environments and life styles in modern China, the main aim of this article is to study associations of respiratory infection outcomes in children with their home environment and life styles.

\section{Methods}

\section{Questionnaire and population}


This study is part of China, Children, Homes and Health (CCHH) project [31, 32]. CCHH in Tianjin consists of two phases: Phase I, a crosssectional study and Phase II, a case-control study. In Phase I, we analyzed data obtained from a questionnaire survey of children's health, demographic information, home environment and life style. We randomly selected daycares and primary schools from a list provided by local Municipal Education Commission. Finally, 24 institutes in urban, 6 in suburban and 9 in rural areas were involved in the survey. Questionnaires were sent to daycare centers and primary schools, from where they were delivered to parents who responded to the questionnaires. The details of questionnaire have been described in another article [28].

Questions on respiratory infections are as follows:

- Has your child ever had croup? (possible responses: yes; no)

- Has your child ever had tuberculosis? (possible response: yes; no)

- Has your child ever had doctor diagnosed pneumonia? (possible response: yes; no)

- Has your child ever had ear infections? (possible response: no; yes, 1-2 times; yes, 3-5 times; yes, $>5$ times)

- In the last 12 months, how many times did your child have a common cold? (possible response: none; 1-2 times; 3-5 times; 6-10 times; $>10$ times)

\section{Statistical analysis}

All statistical analyses were performed with IBM SPSS Statistics 22 . We accepted $P$-values $<0.05$ as statistically significant. We first analyzed children's respiratory infections and their distribution by gender, age, atopy history and home location. Then, the associations of childhood respiratory infections with home environment, lifestyles and biological factors were analyzed in univariate logistic regression models. Finally, those factors with $P$-value $<0.05$ were used in multivariate logistic regression models (using a forward conditional method) to identify the most important risk factors for respiratory infections among children.

Population attributable fraction (PAF) is an estimate of the fraction of population with the health outcome that can be attributed to a particular risk factor or exposure. We calculated PAF for a given exposure using the following formula [33]:

$\mathrm{PAF}=\mathrm{Pe}(\mathrm{RR}-1) /[\mathrm{Pe}(\mathrm{RR}-1)+1]$

where $\mathrm{Pe}$ is the population distribution of the exposure to the factor of interest and RR is the relative risk.

The Research Office at Tianjin University granted ethical approval for this study.

\section{Results}

\subsection{Demographic information and respiratory infections in children}

We have received 7865 questionnaires, a response rate of $78 \%$. Ages were not reported for 204 children, while 295 children did not fit into the age range ( 0 to 8 years old). Therefore, there are 7366 children in the final analysis. Among these 7366 children, $52 \%$ were boys and $48 \%$ were girls.

Table 1 shows that children's respiratory infections, except tuberculosis (TB), had significant associations with family allergy history and home locations $(P<0.05)$. Urban children had more infections compared to rural children. Croup was reported more often for boys. 
Table 1

Respiratory infections among children in Tianjin, China, $\mathrm{n}(\%)$

\begin{tabular}{|c|c|c|c|c|c|c|c|c|c|c|}
\hline & \multicolumn{2}{|l|}{ Croup } & \multicolumn{2}{|c|}{ Tuberculosis (TB) } & \multicolumn{2}{|l|}{ Pneumonia } & \multicolumn{2}{|c|}{ Ear infection } & \multicolumn{2}{|c|}{$\begin{array}{l}\text { Common cold } \\
\text { 凤2 times }\end{array}$} \\
\hline & $\begin{array}{l}\text { Lifetime- } \\
\text { ever } \\
\text { incidence }\end{array}$ & P-value ${ }^{a}$ & $\begin{array}{l}\text { Lifetime- } \\
\text { ever } \\
\text { incidence }\end{array}$ & P-value & $\begin{array}{l}\text { Lifetime- } \\
\text { ever } \\
\text { incidence }\end{array}$ & P-value & $\begin{array}{l}\text { Lifetime- } \\
\text { ever } \\
\text { incidence }\end{array}$ & P-value & $\begin{array}{l}\text { Incidence } \\
\text { per year }\end{array}$ & P-value \\
\hline Total & $625(9.2)$ & / & $51(0.7)$ & / & $\begin{array}{l}1959 \\
(28.7)\end{array}$ & / & $\begin{array}{l}794 \\
(11.6)\end{array}$ & / & $\begin{array}{l}2044 \\
(31.3)\end{array}$ & / \\
\hline \multicolumn{11}{|l|}{ Gender } \\
\hline Male & $\begin{array}{l}364 \\
(10.4)\end{array}$ & \multirow[t]{2}{*}{0.000} & $31(0.9)$ & \multirow[t]{2}{*}{0.211} & $1043(29.8)$ & \multirow[t]{2}{*}{0.064} & $411(11.7)$ & \multirow[t]{2}{*}{0.707} & 1059(31.8) & \multirow[t]{2}{*}{0.445} \\
\hline Female & $254(7.9)$ & & $20(0.6)$ & & $898(27.8)$ & & $373(11.4)$ & & $964(30.9)$ & \\
\hline \multicolumn{11}{|l|}{ Age } \\
\hline $0-2$ & $21(10.0)$ & \multirow[t]{3}{*}{0.755} & $0(0.0)$ & \multirow[t]{3}{*}{0.431} & $52(24.0)$ & \multirow[t]{3}{*}{0.227} & $9(4.3)$ & \multirow[t]{3}{*}{0.001} & $70(36.5)$ & \multirow[t]{3}{*}{0.000} \\
\hline $3-5$ & 268(8.9) & & $23(0.8)$ & & $878(29.3)$ & & $378(12.5)$ & & 1112(38.8) & \\
\hline $6-8$ & $336(9.4)$ & & $28(0.8)$ & & $1029(28.6)$ & & $407(11.2)$ & & $862(24.9)$ & \\
\hline \multicolumn{11}{|c|}{ Family Allergy History } \\
\hline Yes & $156(26.9)$ & \multirow[t]{2}{*}{0.000} & $12(1.3)$ & \multirow[t]{2}{*}{0.016} & $421(45.3)$ & \multirow[t]{2}{*}{0.000} & $176(19.1)$ & \multirow[t]{2}{*}{0.000} & 392(43.8) & \multirow[t]{2}{*}{0.000} \\
\hline No & 433(7.8) & & $33(0.6)$ & & $1436(25.8)$ & & $584(10.4)$ & & 1575(29.7) & \\
\hline \multicolumn{11}{|c|}{ Home Location } \\
\hline Urban & $375(11.0)$ & \multirow[t]{3}{*}{0.000} & $17(0.5)$ & \multirow[t]{3}{*}{0.087} & $1202(35.2)$ & \multirow[t]{3}{*}{0.000} & $545(16.0)$ & \multirow[t]{3}{*}{0.000} & 1137(33.8) & \multirow[t]{3}{*}{0.000} \\
\hline Suburban & 107(7.7) & & $12(0.8)$ & & $333(23.8)$ & & $130(9.2)$ & & $406(30.2)$ & \\
\hline Rural & $105(6.5)$ & & $17(1.0)$ & & $331(20.5)$ & & $75(4.5)$ & & $387(26.3)$ & \\
\hline
\end{tabular}

\subsection{Home environmental factors related to respiratory infections 3.2.1. Dampness, odors and respiratory infections.}

Dampness indicators and odors were defined as follows:

(1) Visible mold in child's room;

(2) Visible damp in child's room;

(3) Suspected moisture problem in child's home;

(4) Floor covering in child's room peeling or discolored;

(5) Flooding in child's room;

(6) Condensation on window pane in winter in child's room;

(7) Moldy odor perception;

(8) Dry air perception. 
Table 2 presents adjusted odd ratios (AOR) of dampness problems for respiratory infections. We found that living in a damp room was associated with increased odds of respiratory infections, especially for croup and TB. Dry air perception was a significant risk factor for all respiratory infections among children.

Table 2

Associations of respiratory infections with dampness and odors

\begin{tabular}{|c|c|c|c|c|c|}
\hline \multicolumn{6}{|c|}{ Adjusted Odds Ratio (AOR), 95\% Confidence Interval (Cl) } \\
\hline & Croup & TB & Pneumonia & Ear infection & $\begin{array}{l}\text { Common cold } \\
>2 \text { times }\end{array}$ \\
\hline \multicolumn{6}{|c|}{ Mold spot in child's room } \\
\hline No & 1.00 & 1.00 & 1.00 & 1.00 & 1.00 \\
\hline Yes & $2.24(1.53,3.28)$ & $8.55(3.93,18.59)$ & $1.00(0.72,1.36)$ & $1.40(0.93,2.09)$ & $1.35(0.99,1.83)$ \\
\hline \multicolumn{6}{|c|}{ Damp spot in child's room } \\
\hline No & 1.00 & 1.00 & 1.00 & 1.00 & 1.00 \\
\hline Yes & $2.09(1.51,2.88)$ & $3.07(1.25,7.50)$ & $1.25(0.97,1.60)$ & $1.46(1.05,2.04)$ & $1.14(0.89,1.47)$ \\
\hline \multicolumn{6}{|c|}{ Suspected moisture in room } \\
\hline No & 1.00 & 1.00 & 1.00 & 1.00 & 1.00 \\
\hline Yes & $1.57(1.25,1.96)$ & $2.16(1.01,4.63)$ & $1.51(1.30,1.76)$ & $1.43(1.16,1.76)$ & $1.28(1.09,1.49)$ \\
\hline \multicolumn{6}{|c|}{ Floor moisture in child's room } \\
\hline No & 1.00 & 1.00 & 1.00 & 1.00 & 1.00 \\
\hline Yes & $1.52(1.04,2.21)$ & $4.02(1.74,9.29)$ & $1.14(0.87,1.50)$ & $1.26(0.88,1.81)$ & $1.33(1.02,1.73)$ \\
\hline \multicolumn{6}{|c|}{ Flooding in child's room } \\
\hline No & 1.00 & 1.00 & 1.00 & 1.00 & 1.00 \\
\hline Yes & $1.83(1.01,3.32)$ & $16.08(6.24,41.45)$ & $1.25(0.78,2.02)$ & $1.27(0.69,2.34)$ & $1.30(0.80,2.10)$ \\
\hline \multicolumn{6}{|c|}{ Condensation on the window pane in child's room } \\
\hline No & 1.00 & 1.00 & 1.00 & 1.00 & 1.00 \\
\hline Yes & $1.56(1.26,1.93)$ & $1.00(0.46,2.16)$ & $1.40(1.22,1.62)$ & $1.06(0.86,1.30)$ & $1.60(1.39,1.83)$ \\
\hline \multicolumn{6}{|c|}{ Moldy odor Perception in room } \\
\hline No & 1.00 & 1.00 & 1.00 & 1.00 & 1.00 \\
\hline Yes & $1.71(1.35,2.18)$ & $3.18(1.60,6.32)$ & $1.28(1.08,1.51)$ & $1.66(1.33,2.07)$ & $1.21(1.02,1.43)$ \\
\hline \multicolumn{6}{|c|}{ Dry air perception in child's room } \\
\hline No & 1.00 & 1.00 & 1.00 & 1.00 & 1.00 \\
\hline Yes & $1.61(1.25,2.07)$ & $2.85(1.32,6.13)$ & $1.57(1.31,1.87)$ & $1.44(1.14,1.82)$ & $1.32(1.10,1.58)$ \\
\hline
\end{tabular}

\subsubsection{Building characteristics and respiratory infections}

Table 3 presents adjusted odds ratios of building characteristics for respiratory infections. Infections (especially pneumonia and ear infections) were associated with new apartment, modern floor covering, modern wall covering and use of air conditioner (AC). Meanwhile exposure to new furniture and redecoration in child's early life due to home renovation was a risk factor for all respiratory infections. Use of biomass/coal for cooking or heating at home was a risk only for TB. 
Table 3

Associations between building characteristics and respiratory infections among children

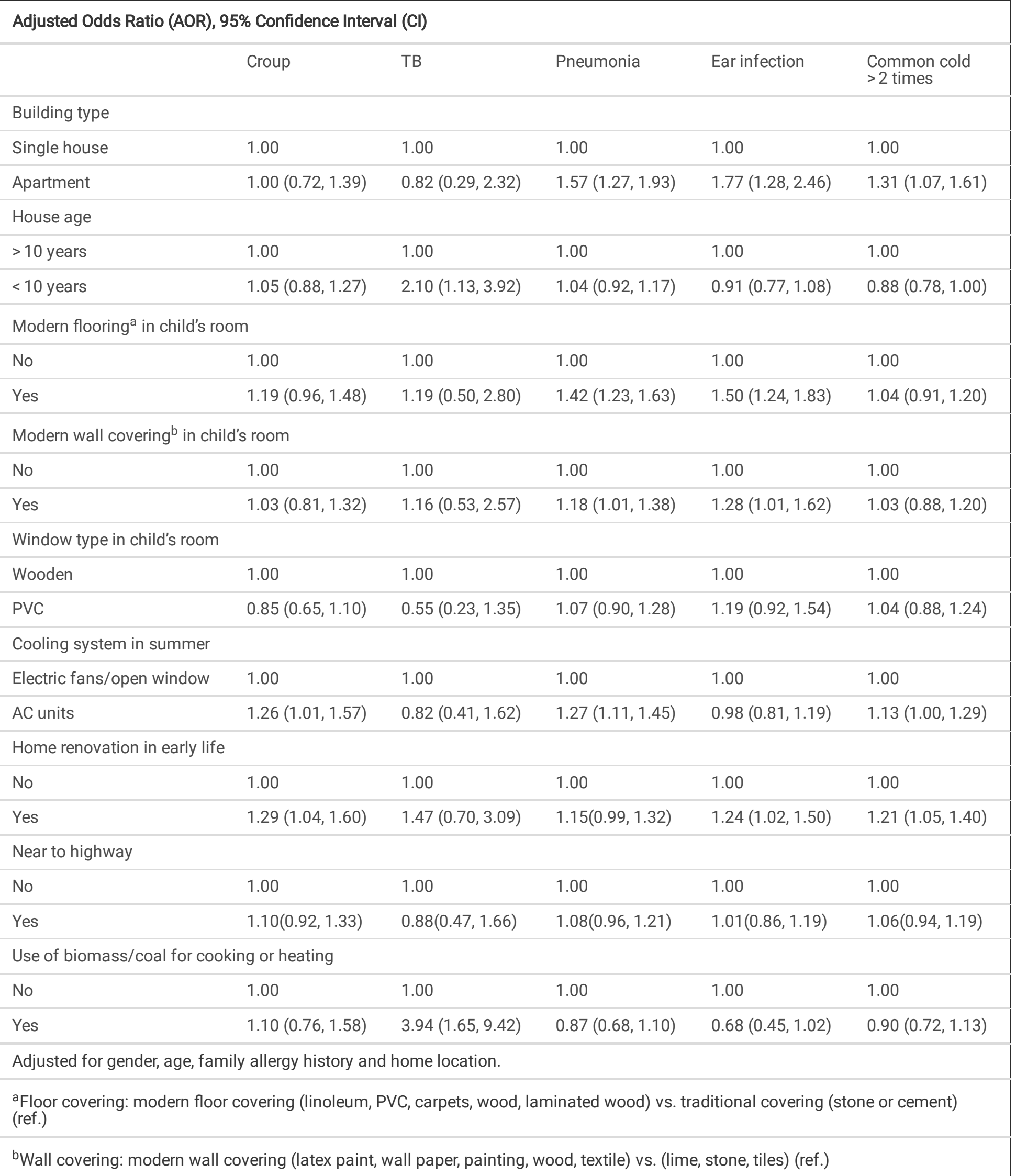

\subsubsection{Environmental tobacco smoke exposure, pet-keeping and respiratory infections}


Table 4 shows adjusted odds ratio of environmental tobacco smoke (ETS) and pet-keeping for respiratory infections. Early life (i.e., during the first year of children's life or during pregnancy) exposure to ETS increased the risks of children's respiratory infections. Mother's smoking was an even stronger risk, especially for croup and TB. Similar to ETS exposure, pet-keeping in children's early life was an even stronger risk factor than current pet keeping for infections.

Table 4

Associations between environmental tobacco smoke exposure, pet-keeping and respiratory infections among children

\begin{tabular}{|c|c|c|c|c|c|}
\hline \multicolumn{6}{|c|}{ Adjusted Odds Ratio (AOR), 95\% Confidence Interval (Cl) } \\
\hline & Croup & TB & Pneumonia & Ear infection & $\begin{array}{l}\text { Common cold } \\
>2 \text { times }\end{array}$ \\
\hline \multicolumn{6}{|c|}{ ETS, current } \\
\hline No & 1.00 & 1.00 & 1.00 & 1.00 & 1.00 \\
\hline Yes & $1.29(1.07,1.55)$ & $0.79(0.43,1.46)$ & $1.18(1.05,1.33)$ & $0.91(0.78,1.07)$ & $0.97(0.87,1.09)$ \\
\hline \multicolumn{6}{|c|}{ Mother smoked, first year of life } \\
\hline No & 1.00 & 1.00 & 1.00 & 1.00 & 1.00 \\
\hline Yes & $3.41(2.00,5.81)$ & $15.50(6.63,36.23)$ & $1.35(0.85,2.15)$ & $1.32(0.70,2.49)$ & $0.94(0.57,1.54)$ \\
\hline \multicolumn{6}{|c|}{ Father smoked, first year of life } \\
\hline No & 1.00 & 1.00 & 1.00 & 1.00 & 1.00 \\
\hline Yes & $1.20(1.00,1.43)$ & $0.98(0.51,1.88)$ & $1.22(1.09,1.37)$ & $0.89(0.76,1.05)$ & $1.00(0.89,1.12)$ \\
\hline \multicolumn{6}{|c|}{ Mother smoked during pregnancy } \\
\hline No & 1.00 & 1.00 & 1.00 & 1.00 & 1.00 \\
\hline Yes & $3.60(1.98,6.55)$ & $11.31(4.14,30.94)$ & $1.26(0.73,2.17)$ & $1.33(0.64,2.76)$ & $0.93(0.53,1.63)$ \\
\hline \multicolumn{6}{|c|}{ Father smoked during pregnancy } \\
\hline No & 1.00 & 1.00 & 1.00 & 1.00 & 1.00 \\
\hline Yes & $1.24(1.04,1.50)$ & $0.95(0.50,1.81)$ & $1.29(1.14,1.45)$ & $0.98(0.83,1.16)$ & $1.04(0.92,1.16)$ \\
\hline \multicolumn{6}{|c|}{ Pet-keeping, current } \\
\hline No & 1.00 & 1.00 & 1.00 & 1.00 & 1.00 \\
\hline Yes & $1.00(0.73,1.26)$ & $0.92(0.42,1.99)$ & $1.15(0.99,1.34)$ & $0.97(0.78,1.21)$ & $1.23(1.06,1.42)$ \\
\hline \multicolumn{6}{|c|}{ Pet-keeping, early life } \\
\hline No & 1.00 & 1.00 & 1.00 & 1.00 & 1.00 \\
\hline Yes & $1.29(1.00,1.68)$ & $2.42(1.21,4.84)$ & $1.05(0.88,1.24)$ & $0.97(0.75,1.26)$ & $1.18(1.00,1.39)$ \\
\hline
\end{tabular}

\subsection{Life style factors related to respiratory infections}

\subsubsection{Daycare attendance and respiratory infections}

Table 5 shows adjusted odds ratios of daycare attendance for the studied respiratory infections among children. Type of child care, starting age of daycare, exposure time and occupancy levels in daycare centers were analyzed. Children in daycare centers were more susceptible to pneumonia and common cold than children who were mostly at home. Children in daycare centers with more than 30 children have a higher morbidity of pneumonia, ear infection and common cold. 
Table 5

Associations between daycare and respiratory infections among children

\begin{tabular}{|c|c|c|c|c|c|}
\hline \multicolumn{6}{|c|}{ Adjusted Odds Ratio (AOR), 95\% Confidence Interval (Cl) } \\
\hline & Croup & TB & Pneumonia & Ear infection & $\begin{array}{l}\text { Common cold } \\
>2 \text { times }\end{array}$ \\
\hline \multicolumn{6}{|l|}{ Type of child care } \\
\hline At home & 1.00 & 1.00 & 1.00 & 1.00 & 1.00 \\
\hline At daycare & $1.03(0.80,1.33)$ & $1.02(0.45,2.29)$ & $1.22(1.04,1.44)$ & $1.14(0.89,1.45)$ & $1.30(1.10,1.53)$ \\
\hline \multicolumn{6}{|c|}{ Starting age of daycare } \\
\hline$>3$ years & 1.00 & 1.00 & 1.00 & 1.00 & 1.00 \\
\hline$<3$ years & $1.06(0.88,1.27)$ & $0.97(0.52,1.81)$ & $0.96(0.85,1.08)$ & $0.97(0.82,1.44)$ & $1.14(1.01,1.28)$ \\
\hline \multicolumn{6}{|c|}{ Time spent in daycare center } \\
\hline$<20$ hours/week & 1.00 & 1.00 & 1.00 & 1.00 & 1.00 \\
\hline$>20$ hours/week & $0.97(0.75,1.24)$ & $0.35(0.16,0.74)$ & $1.08(0.92,1.27)$ & $1.35(1.06,1.72)$ & $1.10(0.93,1.28)$ \\
\hline \multicolumn{6}{|c|}{ Size of the class at daycare center } \\
\hline$<30$ children & 1.00 & 1.00 & 1.00 & 1.00 & 1.00 \\
\hline > 30 children & $0.87(0.72,1.06)$ & $0.77(0.39,1.49)$ & $1.34(1.19,1.51)$ & $1.49(1.26,1.75)$ & $1.34(1.19,1.51)$ \\
\hline
\end{tabular}

\subsubsection{Food habit, outdoor activity, cleaning habit and respiratory infections}

Adjusted odds ratios for food habits, outdoor activity and cleaning habits for respiratory infections are presented in Table 6 . Fruit consumption was a protective factor for children's infections, especially TB, while fast food consumption was a risk factor for all infections. Spending $\geq 3$ hours per day watching TV was a strong risk for common cold, whereas outdoor activities more than 2 times a week was associated with a much lower TB incidence. Children living in a frequently cleaned room with good ventilation and frequently sun-cured bedding had fewer respiratory infections. 
Table 6

Associations of respiratory infections among children with dietary habits, outdoor activity, cleaning habits, sun-curing bed sheets and window-opening behavior

\begin{tabular}{|c|c|c|c|c|c|}
\hline \multicolumn{6}{|c|}{ Adjusted Odds Ratio (AOR), 95\% Confidence Interval (Cl) } \\
\hline & Croup & TB & Pneumonia & Ear infection & $\begin{array}{l}\text { Common cold } \\
>2 \text { times }\end{array}$ \\
\hline \multicolumn{6}{|l|}{ Fruit consumption } \\
\hline Occasionally/never & 1.00 & 1.00 & 1.00 & 1.00 & 1.00 \\
\hline$\geq$ once/week & $0.58(0.32,1.03)$ & $0.27(0.08,0.92)$ & $0.80(0.52,1.23)$ & $0.70(0.38,1.28)$ & $1.36(0.83,2.22)$ \\
\hline \multicolumn{6}{|c|}{ Fast food consumption } \\
\hline Occasionally/never & 1.00 & 1.00 & 1.00 & 1.00 & 1.00 \\
\hline$\geq$ once/week & $1.10(0.87,1.41)$ & $2.08(0.97,4.48)$ & $1.05(0.89,1.23)$ & $1.05(0.85,1.31)$ & $1.00(0.85,1.17)$ \\
\hline \multicolumn{6}{|l|}{ Watching TV } \\
\hline$<3$ hours per day & 1.00 & 1.00 & 1.00 & 1.00 & 1.00 \\
\hline$\geq 3$ hours per day & $1.33(0.96,1.86)$ & $2.28(0.98,5.27)$ & $0.99(0.78,1.25)$ & $1.09(0.78,1.53)$ & $1.33(1.06,1.66)$ \\
\hline \multicolumn{6}{|l|}{ Outdoor activity } \\
\hline$\leq 2$ times per week & 1.00 & 1.00 & 1.00 & 1.00 & 1.00 \\
\hline$>2$ times per week & $1.24(1.03,1.50)$ & $0.38(0.19,0.77)$ & $0.98(0.87,1.10)$ & $0.97(0.82,1.14)$ & $1.02(0.91,1.15)$ \\
\hline \multicolumn{6}{|l|}{ Cleaning room } \\
\hline Everyday & 1.00 & 1.00 & 1.00 & 1.00 & 1.00 \\
\hline Less than everyday & $1.11(0.92,1.35)$ & $0.70(0.32,1.51)$ & $1.17(1.03,1.33)$ & $1.40(1.19,1.66)$ & $1.15(1.02,1.30)$ \\
\hline \multicolumn{6}{|l|}{ Opening window } \\
\hline Everyday & 1.00 & 1.00 & 1.00 & 1.00 & 1.00 \\
\hline Less than everyday & $1.04(0.70,1.53)$ & $3.49(1.58,7.71)$ & $0.97(0.76,1.25)$ & $0.94(0.65,1.37)$ & $1.09(0.86,1.39)$ \\
\hline \multicolumn{6}{|l|}{ Sun-curing bed sheets } \\
\hline Often & 1.00 & 1.00 & 1.00 & 1.00 & 1.00 \\
\hline Not often & $1.30(1.07,1.58)$ & $1.15(0.56,2.35)$ & $1.50(1.33,1.70)$ & $1.53(1.28,1.83)$ & $1.33(1.18,1.50)$ \\
\hline
\end{tabular}

\subsection{Biological Factors}

Table 7 presents adjusted odds ratios of biological factors for respiratory infections among children. Caesarean delivery is significantly associated with croup, pneumonia and ear infection. Children who were not born on due week with less birth weight had a higher morbidity of croup and pneumonia 
Table 7

Associations between children's biological factors and respiratory infections

\begin{tabular}{|c|c|c|c|c|c|}
\hline \multicolumn{6}{|c|}{ Adjusted Odds Ratio (AOR), 95\% Confidence Interval (Cl) } \\
\hline & Croup & TB & Pneumonia & Ear infection & $\begin{array}{l}\text { Common cold } \\
>2 \text { times }\end{array}$ \\
\hline \multicolumn{6}{|c|}{ Way of delivery } \\
\hline Natural & 1.00 & 1.00 & 1.00 & 1.00 & 1.00 \\
\hline Caesarean & $1.23(1.02,1.49)$ & $0.94(0.50,1.77)$ & $1.27(1.13 .1 .43)$ & $1.25(1.06,1.49)$ & $0.98(0.87,1.10)$ \\
\hline \multicolumn{6}{|c|}{ Period of breastfeeding } \\
\hline$>6$ months & 1.00 & 1.00 & 1.00 & 1.00 & 1.00 \\
\hline$<6$ months & $1.09(0.90,1.34)$ & $1.68(0.83,3.40)$ & $1.10(0.97,1.25)$ & $1.17(0.99,1.40)$ & $0.92(0.80,1.04)$ \\
\hline \multicolumn{6}{|c|}{ Born on due week } \\
\hline Yes & 1.00 & 1.00 & 1.00 & 1.00 & 1.00 \\
\hline No & $1.22(1.01,1.46)$ & $1.83(0.96,3.48)$ & $1.29(1.14,1.45)$ & $1.11(0.94,1.31)$ & $0.98(0.87,1.11)$ \\
\hline \multicolumn{6}{|l|}{ Birth weight } \\
\hline$>2.5 \mathrm{~kg}$ & 1.00 & 1.00 & 1.00 & 1.00 & 1.00 \\
\hline$<2.5 \mathrm{~kg}$ & $1.08(0.72,1.62)$ & $1.41(0.43,4.61)$ & $1.41(1.10,1.80)$ & $1.25(0.89,1.76)$ & $1.04(0.80,1.34)$ \\
\hline
\end{tabular}

\subsection{Multivariate regression model and population attributable fraction}

Multivariate analysis of associations of respiratory infections with home environment, life styles and biological factors is shown in Table 8. Condensation on window pane, moldy/dry air perception, modern decoration materials, less frequency of sun-curing bed sheets and cesarean delivery were the greatest risk factors for croup, pneumonia, ear infections and common colds. In addition, attending daycare increased the risk of common colds. 
Table 8

Associations of respiratory infections among children with home environment, life styles and biological factors in Tianjin, China

Adjusted Odds Ratio (AOR), 95\% Confidence Interval (Cl)

$\begin{array}{cccc}\text { Croup TB Pneumonia Earinfection } & \begin{array}{l}\text { Common cold } \\ >2 \text { times }\end{array}\end{array}$

Mold/damp spot ${ }^{a}$

Suspected moisture ${ }^{b}$

$1.36(1.10,1.69)$

Condensation $^{c}$

$1.43(1.08,1.88)$

$1.56(1.31,1.87)$

Moldy odor perception ${ }^{d}$

$1.56(1.08,2.25)$

$1.78(1.27,2.49)$

Dry air perception ${ }^{\mathrm{e}}$

$1.39(1.07,1.80)$

$1.47(1.13,1.90)$

Modern floor covering ${ }^{f}$

$1.30(1.06,1.60)$

$1.35(1.02,1.79)$

Modern wall covering ${ }^{g}$

Renovation, early ${ }^{h}$

$1.47(1.13,1.91)$

$1.29(1.06,1.57)$

ETS exposure, early ${ }^{\mathrm{i}}$

$1.30(1.10,1.54)$

Pet keeping, early ${ }^{j}$

Air Conditionerk

Daycare attendance

$1.21(1.03,1.44)$

Cleaning room ${ }^{\mathrm{m}}$

Sun-curing bedding ${ }^{\mathrm{n}}$

$1.29(1.08,1.54)$

$1.47(1.14,1.90)$

$1.22(1.03,1.44)$

Cesarean delivery ${ }^{\circ}$

$1.43(1.07,1.91)$

$1.27(1.06,1.52)$

$1.42(1.09,1.86)$

Adjusted for gender, age, family allergy history and home location. Forward conditional method is applied.

aVisible mold or damp spots in child's room: yes vs. no (ref.)

${ }^{b}$ Suspected moisture problem in child's home: yes vs. no (ref.)

${ }^{c}$ Condensation on window pane in winter: yes vs. no (ref.)

dPerceived moldy odor in room: yes vs. no (ref.)

ePerceived dry air in room: yes vs. no (ref.)

fFloor covering: modern floor covering (linoleum, PVC, carpets, wood, laminated wood) vs. traditional covering (stone or cement) (ref.)

gWall covering: modern wall covering (latex paint, wall paper, painting, wood, textile) vs. (lime, stone, tiles)

${ }^{\text {h}}$ Home renovation during child's early life: yes vs. no (ref.)

'Parents smoking during child's early life: yes vs. no (ref.)

jPet-keeping during child's early life: yes vs. no (ref.)

kUse of air conditioner: yes vs. no (ref.)

'Daycare attendance: child goes to daycare center vs. stays at home (ref.)

${ }^{m}$ Cleaning room: less frequently than everyday vs. everyday (ref.) 


\section{Adjusted Odds Ratio (AOR), 95\% Confidence Interval (Cl)}

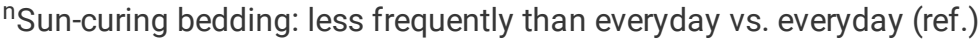

${ }^{\circ}$ Mode of delivery: cesarean delivery vs. natural delivery (ref.)

The PAFs of home environmental, life styles and biological factors for infections among children are shown in Table 9. Dry air perception is the top contributor to childhood pneumonia and common cold, while it is cesarean delivery for croup and ear infection. Daycare attendance, a secondary attribution factor, contributes $14.4 \%$ to frequent common cold. In addition, less frequent sun-cure bedding is a risk factor for pneumonia, ear infection and common colds, as are modern floor coverings, renovation during the child's early life and perceived moldy odor.

Table 9

Population attributable fractions of home environment, lifestyles and biological factors for respiratory infections among children in Tianjin, China

\begin{tabular}{|c|c|c|c|c|c|}
\hline & Croup, \% & TB, \% & Pneumonia, \% & Ear infection, \% & $\begin{array}{l}\text { Common cold } \\
>2 \text { times, \% }\end{array}$ \\
\hline \multicolumn{6}{|l|}{ Mold/damp spot } \\
\hline Suspected moisture & & & 5.1 & & \\
\hline Condensation & 8.4 & & & & 10.3 \\
\hline Moldy odor perception & 6.1 & & & 8.4 & \\
\hline Dry air perception & & & 14.6 & & 16.8 \\
\hline Modern floor covering & & & 10.3 & 12.3 & \\
\hline \multicolumn{6}{|l|}{ Modern wall covering } \\
\hline Renovation, early & & & & 6.8 & 4.8 \\
\hline ETS exposure, early & & & 11.2 & & \\
\hline \multicolumn{6}{|l|}{ Pet keeping, early } \\
\hline \multicolumn{6}{|l|}{ Air Conditioner } \\
\hline Daycare attendance & & & & & 12.3 \\
\hline \multicolumn{6}{|l|}{ Cleaning room } \\
\hline Sun-curing bedding & & & 11.2 & 17.1 & 8.6 \\
\hline Cesarean delivery & 18.7 & & 12.0 & 18.5 & \\
\hline
\end{tabular}

\section{Discussion}

In this study, a multivariate regression model was applied to identify the greatest home environmental risks for children's infections. Perceived dry air had the strongest association with pneumonia and common colds. The reported rate of "dry air perception" is high in Tianjin, 53.1\% in our study. We found that dryness was significantly associated with dampness indicators, consistent with findings from previous studies [34] [35] [36]. "Perceived dry air" has been shown to not necessarily be due to physically dry indoor air [37] but rather to polluted air. Building dampness promotes the growth of, mould [38], as well as increases VOC emissions from building material [39], which may result in "dry air perception".

Condensation on the child's room window panes in winter was a strong risk for respiratory infections among children. Condensation on windowpanes in winter was reported to be an indicate of insufficient ventilation in homes [40,41]. Chinese homes do not have a mechanical ventilation system. Most of residential buildings in China still depend on "window ventilation" or infiltration to passively introduce outdoor air to indoors. In Tianjin winter, 90\% of homes closed window at night. Ventilation is mainly through infiltration, with a median value of $0.30 \mathrm{~h}^{-1}$ [30]. In such tight buildings poor ventilation rate could not efficiently dilute airborne-transmitted pathogens 
and thus result in their accumulation in our occupied spaces. A study conducted in army trainees found that rates of febrile acute respiratory diseases were significantly higher among trainees in modern (energy efficient design) barracks (adjusted relative risk 1.51) [42]. Mendell estimated that in offices with lower ventilation, relative risk for short-term sick leave was $1.53(95 \% \mathrm{Cl} 1.22-1.92)$ [43]. A study conducted in Peru indicated that after simple modifications to existing hospital infrastructure, the rate of natural ventilation increased considerably and the estimated reduction in risk of TB infection was 72\% (inter-quartile range 51-82\%) [44].

In addition to the modern practice of tight buildings, more and more modern materials are being used for indoor furnishings and decoration [45]. China is currently the largest producer of wood-based panels, coating and furniture in the world. Massive new building furnishing materials have emerged in people's daily life. In our study, children who live in urban apartment decorated with modern floor and wall covering were reported to have more respiratory infections. Renovation during the first year of children's life was also a risk. Considerable evidence has demonstrated that the chemical emissions of modern indoor materials (new wall coverings, new furniture, new synthetic carpets) are associated with increases in respiratory infections among children or infants [46]. Home renovation and modern decoration materials are positively associated with high concentrations of formaldehyde and volatile organic compounds (VOCs) [47]. These indoor pollutants may affect the human health by developmental delays in children, reduced activity of the immune system and direct toxicity. As a comparison, suburban or rural children who lived in Pingfang with less "modern" redecoration and materials had fewer respiratory infections. Pingfang children mostly spend more time outdoors and thus are less exposed to indoor pollution, which may be a reasonable explanation for lower incidence of respiratory infections in suburban and rural areas [48].

Among life style factors, we found associations of respiratory infections with Cesarean delivery and daycare attendance. In particular, cesarean delivery was a significant risk factor with a high PAF for childhood croup, pneumonia and ear infection. Bosch et al [24] pointed out that cesarean delivery affected early respiratory microbiota development, thereby possibly increasing the morbidity of respiratory infections later in life. In our study, the Cesarean delivery rate was $62 \%$ in Tianjin, higher than the national level of $46 \%$ [49] and the recommended value by WHO of $15 \%$ [50].

Consistent with studies in America [51] and Sweden [52] our analysis demonstrated that daycare attendance was a significant risk factor for common cold among children in Tianjin. Daycare occupancy level and weekly exposure time are measures of contact with other children. We found that children spending more time in daycare or in higher occupancy daycare centers were susceptible to have pneumonia, ear infections and common colds. Daycare attendance was a contributor for common cold infections (See Table 9, PAF = $12.3 \%)$, second only to dry air perception. More frequent contacts with persons may be the reasonable explanations for this observation. For respiratory infection viruses such as influenza, adenovirus, rhinovirus, and coronavirus, which transmitted by small particle aerosols, airborne transmission is considered the predominant transmission pathway [53, 54], however contact (direct or indirect) can also spread these pathogens. A study on the transmission of common cold in sharing offices indicated that workers sharing offices have a significant risk of common cold than those working in single rooms (AOR 1.35) [55]. Overcrowding in a large urban jail was reported to be a significant risk factor $(p=0.03)$ for an outbreak of pneumococcal disease among inmates [56]. Likewise, an early case-control study in American showed that inmates infected with TB were less likely than "healthy" inmates to have a TV in their individual cells (42\% vs. $87 \% ; p=0.003$ ) and spent more time in the communal day room (median, $28 \mathrm{~h} /$ week vs. $3 \mathrm{~h} /$ week; $p=0.01$ ), thus more contacts with infected inmates [57].

Currently in China, approximately 250 million households (accounting for $55 \%$ of population in China) live in cities. Rapid urbanization and modernization has led China to experience a dramatic change in both indoor environment and lifestyles in the past two decades. Modern high-rise apartments are constructed tightly and decorated with modern materials. The result is insufficient ventilation that results in increased concentrations of indoor-generated pollutants, including chemical compounds and airborne transmitted pathogens. It is almost impossible to sun-cure bedding frequently in modern urban buildings. The Cesarean delivery rate is higher due in part to hospitals' financial motivation [49]. It is common that children attend daycare centers around three years old since generally, both parents work. Meanwhile more health issues related to indoor environment are noticed.

Parallel CCHH studies performed in other cities have found similarly high rates of respiratory infections in children, especially in urban areas $[19,31]$. The incidence of lifetime-ever pneumonia among children in modern cities, like Tianjin, 28.7\%, are substantially higher than those in USA and European cities [58]. Pneumonia is an infectious disease caused by bacteria or virus. The high infection rate of pneumonia in China may be partially due to insufficient vaccine coverage with Pneumococcal Conjugate Vaccine (PCV) and Haemophilus Influenzae Type b (Hib) vaccine. However, the incidence and severity or duration of pneumonia could be influenced by environmental factors [59]. Our analysis in the present study was hierarchical so as to identify the important factors among a variety of possible risk factors. The most prominent risk factors from multivariate analysis were related to modern home environment and life 
styles. The higher rates of childhood respiratory infections are linked with the combination of nutritional, environmental and behavioral influences, which affect the development of immune system and the breeding and transmission of pathogen.

\section{Conclusions}

Condensation on the window pane in winter, dry air perception, infrequent sun-curing of bedding and cesarean delivery are the strongest risks for all studied childhood respiratory infections except TB. "Modern" home environment and lifestyles play an important role in the incidence of respiratory infections among children. Increasing ventilation rate, frequent sun-curing of bedding and avoiding unnecessary Cesarean delivery would be effective measures to reduce the incidence of childhood respiratory infections.

\section{Declarations}

\section{Ethics approval and consent to participate}

Ethics approval was given by the Research Office of Tianjin University.

\section{Consent for publication}

Not applicable.

\section{Availability of data and materials}

The datasets used and/or analyzed during the current study are available from the corresponding author on reasonable request.

\section{Competing interests}

The authors declare that they have no competing interests.

\section{Funding}

This study was funded by the National Key Research and Development Program of China (2017YFC0702700) and the National Natural Science Foundation of China (21207097).

\section{Acknowledgements}

Special appreciation to Louise B. Weschler, who has polished our language and clarified our expression.

\section{Authors' information}

\section{Affiliations}

Tianjin Key Laboratory of Indoor Environment Quality Control, School of Environment Science and Engineering, Tianjin University, Yaguan Road 135, Jinnan District, Tianjin 300350, China

Dachao Lv, Yuexia Sun, Jing Hou, Pan Wang, Qingnan Zhang, Jan Sundell

\section{Contributions}

Dachao Lv contributed to literature review, data analysis, data interpretation and writing. Yuexia Sun contributed to study design, data collection, data analysis and writing. Jing Hou, Pan Wang and Qingnan Zhang contributed to data collection and writing. Jan Sundell contributed to study design, data interpretation and writing.

\section{Corresponding author}

Correspondence to Yuexia Sun.

\section{Abbreviations}

$\mathrm{CCHH}$ : China, Children, Homes and Health 
TB: Tuberculosis

ETS: Environmental tobacco smoke

PAF: Population attributable fractions

AC: Air conditioner

AOR: Adjusted odds ratio

Cl: Confidence interval

\section{References}

1. Mizgerd J P. Lung Infection-A Public Health Priority[J]. Plos Medicine, 2006, 3(2): e76.

2. UNICEF, WHO, World Bank \& UN-DESA Population Division (2018). Levels \& trends in child mortality report 2018. https://childmortality.org/reports

3. World health statistics 2018: monitoring health for the SDGs, sustainable development goals. who.int/gho/publications/world_health_statistics/en/

4. Wong G W K, Chow C M. Childhood asthma epidemiology: Insights from comparative studies of rural and urban populations. Pediatr Pulmonol, 2008, 43: 107-116

5. Wong G W K, Hui D S C, Chan C C, et al. Prevalence of respiratory and atopic disorders in Chinese schoolchildren. Clin Exp Allergy, 2001, 31: 1225-1231

6. Leech J A, Nelson W C, Burnett R T, et al. It's about time: A comparison of Canadian and American time-activity patterns[J]. Journal of Exposure Analysis \& Environmental Epidemiology, 2002, 12(6):427-432.

7. Brasche S, Bischof W. Daily time spent indoors in German homes - Baseline data for the assessment of indoor exposure of German occupants[J]. Int J Hyg Environ Health, 2006, 208(4):247-253.

8. Gordon S B, Bruce N G, Grigg J, et al. Respiratory risks from household air pollution in low and middle income countries[J]. Lancet Respiratory Medicine, 2014, 2(10):823-860.

9. Tham K W, Zuraimi M S, Koh D, et al. Association between home dampness and presence of molds with asthma and allergic symptoms among young children in the tropics[J]. Pediatric Allergy \& Immunology, 2010, 18(5):418-424.

10. Tsao Y C, Hwang Y H. Impact of a water-damaged indoor environment on kindergarten student absences due to upper respiratory infection[J]. Building \& Environment, 2013, 64(64):1-6.

11. Kennedy K, Grimes C. Indoor water and dampness and the health effects on children: a review[J]. Current Allergy \& Asthma Reports, 2013, 13(6):672-680.

12. Mendell M J, Mirer A G, Cheung K, et al. Respiratory and Allergic Health Effects of Dampness, Mold, and Dampness-Related Agents: A Review of the Epidemiologic Evidence[J]. Environmental Health Perspectives, 2011, 119(6):748-756.

13. Fisk WJ, Eliseeva, EA, Mendell, MJ, et al. Association of residential dampness and mold with respiratory tract infections and bronchitis: a meta-analysis[J]. Environmental Health, 2010, 9: 72.

14. Bronswijk J. E. M. H. van. House dust biology for allergists, acarologists and mycologists[M]. 1981.

15. Waegemaekers M, Van W N, Brunekreef B, et al. Respiratory symptoms in damp homes. A pilot study[J]. Allergy, 2010, 44(3):192-198.

16. Dong G H, Cao Y, Ding H L, et al. Effects of environmental tobacco smoke on respiratory health of boys and girls from kindergarten: results from 15 districts of northern China[J]. Indoor Air, 2010, 17(6):475-483.

17. Mendell M J. Indoor residential chemical emissions as risk factors for respiratory and allergic effects in children: a review[J]. Indoor air, 2007, 17(4):259-277.

18. Nesti M M, Goldbaum M. Infectious diseases and daycare and preschool education[J]. Jornal De Pediatria, $2007,83(4): 299$.

19. Zhuge $Y$, Qian H, Zheng X, et al. Residential risk factors for childhood pneumonia: A cross-sectional study in eight cities of China[J]. Environment International, 2018, 116:83-91.

20. Holberg C J, Wright A L, Martinez F D, et al. Child day care, smoking by caregivers, and lower respiratory tract illness in the first 3 years of life. Group Health Medical Associates[J]. Pediatrics, 1993, 91(5):885. 
21. Ball T M, Castrorodriguez J A, Griffith K A, et al. Siblings, day-care attendance, and the risk of asthma and wheezing during childhood[J]. N Engl J Med, 2000, 343(26):538-543.

22. Louhiala $\mathrm{P}$ J, Jaakkola N, Ruotsalainen R, et al. Form of day care and respiratory infections among Finnish children[J]. American Journal of Public Health, 1995, 85(8 Pt 1):1109.

23. Hardy A M, Fowler M G. Child care arrangements and repeated ear infections in young children[J]. American Journal of Public Health, 1993, 83(9):1321-1325.

24. Bosch A A T M, Levin E, Van Houten M A, et al. Development of Upper Respiratory Tract Microbiota in Infancy is Affected by Mode of Delivery[J]. EBioMedicine, 2016, 9:336-345.

25. Victora C G, Barros A, Fuchs S C, et al. WHO collaborative study team on the role of Breastfeeding on the prevention of infant mortality. Effect of breastfeeding on infant and child mortality due to infectious diseases in less developed country: A pooled analysis[J]. Lancet, 2000, 355(9202):451-455.

26. Ip S, Chung M, Raman G, et al. Breastfeeding and maternal and infant health outcomes in developed countries[J]. Evidence Report/technology Assessment, 2007, 153(153):1.

27. Arifeen S, Black R E, Antelman G, et al. Exclusive Breastfeeding Reduces Acute Respiratory Infection and Diarrhea Deaths Among Infants in Dhaka Slums[J]. PEDIATRICS, 2001, 108(4): e67-e67.

28. Sun Y, Hou J, Sheng Y, et al. Modern life makes children allergic. A cross-sectional study: associations of home environment and lifestyles with asthma and allergy among children in Tianjin region, China[J]. International Archives of Occupational and Environmental Health, 2019, 92(4):587-589.

29. Zhang Y, Mo J, Weschler C J. Reducing Health Risks from Indoor Exposures in Rapidly Developing Urban China[J]. Environmental Health Perspectives, 2013, 121(7):751-755.

30. Hou J, Zhang Y P, Sun Y X, et al. Air change rates at night in northeast Chinese homes[J]. Building \& Environment, 2018, 132:273281.

31. Zhang Y P, Li B Z, Huang C, et al. Ten cities cross-sectional questionnaire survey of children asthma and other allergies in China[J]. Chinese Science Bulletin, 2013, 58(34):4182-4189.

32. Sundell J, Li BZ, Zhang YP (2013) China, Children, Homes, Health (CCHH). Chinese Sci Bull 58(34):4179-4181

33. Rockhill B, Newman B, Weinberg C. Use and misuse of population attributable fractions[J]. American Journal of Public Health, 1998, 88(1):15-19.

34. Bu Z, Wang L, Weschler L B, et al. Associations between perceptions of odors and dryness and children's asthma and allergies: A cross-sectional study of home environment in Baotou[J]. Building and Environment, 2016, 106:167-174.

35. Sundell J, Lindvall T. Indoor Air Humidity and Sensation of Dryness as Risk Indicators of SBS [J]. Indoor Air-international Journal of Indoor Air Quality and Climate, 1993, 3(4):382-390.

36. Fang L. Impact of indoor air temperature and humidity in an office on perceived air quality, SBS symptoms and performance[J]. Indoor Air, 2010, 14(s7):74-81.

37. Andersen I, Lundqvist GR, Jensen PL, Proctor DF. Human response to 78-hour exposure to dry air[J]. Arch Environ Health,1974, 29:319-324

38. Nevalainen A, Pasanen A L, Niininen M, et al. The Indoor Air Quality in Finnish Homes with Mold Problems[J]. Environment International, 1991, 17(4):299-302.

39. Schlink U, Thiem A, Kohajda T, et al. Quantile regression of indoor air concentrations of volatile organic compounds (VOCs)[J]. Science of the Total Environment, 2010, 408(18):3840-3851.

40. Hou J, Zhang Y P, Sun Y X, et al. Air change rates at night in northeast Chinese homes[J]. Building \& Environment, $2018,132$.

41. Emenius G, Svartengren M, Korsgaard J, et al. Building characteristics, indoor air quality and recurrent wheezing in very young children (BAMSE) [J]. Indoor Air, 2004, 14(1):34-42.

42. Brundage, John F. Building-Associated Risk of Febrile Acute Respiratory Diseases in Army Trainees[J]. JAMA: The Journal of the American Medical Association, 1988, 259(14):2108.

43. Milton D K, Glencross P M , Walters M D . Risk of Sick Leave Associated with Outdoor Air Supply Rate, Humidification, and Occupant Complaints[J]. Indoor Air, 2001, 10(4):212-221.

44. Escombe A R, Ticona E, Chávez-Pérez, Víctor, et al. Improving natural ventilation in hospital waiting and consulting rooms to reduce nosocomial tuberculosis transmission risk in a low resource setting[J]. BMC Infectious Diseases, 2019, 19(1). 
45. Wang L X, Zhao B, Liu C, et al. Indoor SVOC pollution in China: A review[J]. Chinese Science Bulletin, 2010, 55(15):1469-1478.

46. Mendell M J. Indoor residential chemical emissions as risk factors for respiratory and allergic effects in children: a review[J]. Indoor Air, 2010, 17(4):259-277.

47. Park J S, Ikeda K. Variations of formaldehyde and VOC levels during 3 years in new and older homes[J]. Indoor Air, 2010, 16(2):129135.

48. Shang Z. A comparative study on the characteristics of outdoor activities of urban and rural children in Shanxi province (In Chinese) [D].

49. Lumbiganon $\mathrm{P}$, Laopaiboon M , Gülmezoglu AM, et al. Method of delivery and pregnancy outcomes in Asia: the WHO global survey on maternal and perinatal health 2007-08[J]. Lancet, 2010, 375(9713):490-499.

50. Althabe F , José M Belizán. Caesarean Section: The Paradox[J]. The Lancet, 2006, 368(9546):1472-1473.

51. Fleming D W, Cochi S L, Hightower A W, et al. Childhood upper respiratory tract infections: to what degree is incidence affected by day-care attendance? [J]. Pediatrics, 1987, 79(1):55-60.

52. Strangert K. Respiratory illness in preschool children with different forms of day care[J]. Pediatrics, $1976,57(2): 191$.

53. Henrickson K J. Viral pneumonia in children[J]. Seminars in Pediatric Infectious Diseases, 1998, 9(3):217-233.

54. Peltola V, Waris M, Österback, Riikka, et al. Rhinovirus Transmission within Families with Children: Incidence of Symptomatic and Asymptomatic Infections[J]. The Journal of Infectious Diseases, 2008, 197(3):382-389.

55. Jaakkola J J, Heinonen O P. Shared office space and the risk of the common cold[J]. European Journal of Epidemiology, 1995, $11(2): 213$.

56. Hoge C W, Reichler M R, Dominguez E A, et al. An Epidemic of Pneumococcal Disease in an Overcrowded, Inadequately Ventilated Jail[J]. New England Journal of Medicine, 1994, 331(10):643-648.

57. Waterman S H. Tuberculosis Outbreak in a Housing Unit for Human Immunodeficiency Virus-Infected Patients in a Correctional Facility: Transmission Risk Factors and Effective Outbreak Control[J]. Clinical Infectious Diseases, 2002, 34(5):668-676.

58. Qu F, Weschler L B, Sun Y X, et al. High pneumonia lifetime-ever incidence in Beijing children compared with locations in other countries, and implications for national PCV and Hib vaccination[J]. PLOS ONE, 2017, 12(2): e171438.

59. Dan N, Chan L, Zhang Y P, et al. Lifetime-ever pneumonia among pre-school children across China - Associations with pre-natal and post-natal early life environmental factors[J]. Environmental Research, 2018, 167:418-427. 